811.163.41:811.112.2](430)

811.163.41'27(430)

81'246.2-054.62(430)

https://doi.org/10.18485/sj.2020.25.1.34

ЈУЛИЈАНА ВУЛЕТИЪ

Универзитет у Крагујевцу

Филолошко-уметнички факултет
Оригинални научни рад

Примљен: 15. 10. 2019.

Прихваћен: 15. 01. 2020.

\title{
УПОТРЕБА СРПСКОГ ЈЕЗИКА У ИНТЕРГЕНЕРАЦИЈСКОЈ И ИНТРАГЕНЕРАЦИЈСКОЈ КОМУНИКАЦИЈИ СРБА У НЕМАЧКОЈ ДИЈАСПОРИ
}

Овај рад представља део резултата до којих смо дошли у истраживању процеса промена српског језика под утицајем немачког у непосредном контакту, надаље појаве феномена непосредног језичког контакта као и замене српског језика немачким језиком. Истраживање је спроведено у немачком граду Инголштату, Баварска, и то у периоду од 2010. до 2013. године на испитаном узорку који чине 27 породица са укупно 83 испитаника. ${ }^{1}$ У раду се конкретно обрађује на који начин, којим средствима и уз које пратеће феномене непосредног језичког контакта Срби у немачкој дијаспори употребаљавају српски језик у међугенерацијској комуникацији.

Кључне речи: интергенерацијска, интрагенерацијска комуникација, трансфер и трансференција, прекључивање кода, неутрализација.

*julijanakg@Rotmail.com

${ }^{1}$ Овај чланак се базира на резултатима истраживања представљених су у необјављеној докторској дисертацији под називом „Процес замене језика и промене изазване контактом српског са немачким језиком у говору Срба у СР Немачкој”. 


\section{1. УВОД}

Проблематика језика у контакту, тачније исхода језичког контакта, као што су прекључивање кодова, трансференција, очување/замена језика и сл., постаје предмет интересовања многих научника и научних дисциплина од тренутка када су 50-их година 20. века земље Западне Европе тражиле радну снагу. Замена/очување језика и остали могући исходи језичког контакта по правилу се јављају као последица друштвених кретања веома присутних у савременом свету (миграције, економски развитак, мобилности појединаца или читавих етничких група и сл.), те нарочито последњих деценија расте интересовање за ову тему на примерима све већег броја језичких парова.

У анализи, коју заснивамо на емпиријски прикупљеним лингвистичким и социолингвистичким подацима, истраживали смо како се мења стање српског језичког система под утицајем система немачког језика услед трансференције у лексикону, синтакси и морфологији ${ }^{2}$ и то у процесу који се креће од једне у правцу друге монолингвалности. Ову системско-лингвистичку анализу комбиновали смо са утицајем друштвених мрежа на степен манифестовања ових контактнолингвистичких феномена у структурама српског језика. Занимало нас је, између осталог, и како се током неумитног процеса замене језика у конкретном случају друштвене мреже одражавају на употребу српског језика, тачније на степен његовог очувања у миграционом контексту.

\section{2. ФЕНОМЕНИ ЈЕЗИЧКОГ КОНТАКТА}

Иако у научној литератури већина научника и истраживача више не користи термин мешање језика (Зел 1988: 130), ми се, овде делимично следећи Фелдеса (Фелдес 2005: 71), опредељујемо да појаве и процесе језичког контакта назовемо општим именом феномени језичког контакта, при чему под мешањем језика подразумевамо управо (дугорочне) резултате трансференције. ${ }^{3}$

У најважније феномене језичког контакта убрајамо 1) двојезичност (вишејезичност) као последицу (настанак пиџина и креола $\left.{ }^{4}\right)$, али и као узрок

${ }^{2}$ Трансференција на фонетско-фонолошкој равни не чини саставни део овог истраживања. Анализа ове језичке равни поред тога што захтева посебне техничке услове и квалитете снимака представља и једну комплексну и посебну област истраживања.

${ }^{3}$ У посредном контакту се ово мешање одражава на промену стандарда једне монолингвалне заједнице са дијахроног аспекта, а у непосредном контакту на настанак дијаспоралног језика у језичком динамизму током трајања животног циклуса једне билингвалне заједнице.

${ }^{4}$ Пиџини су производ адаптације природних језика који су се развили међу људима који немају заједнички језик, а желе међусобно да разговарају, из трговачких или неких других разлога. Већина пиџина заснива се на европским језицима - енглеском, француском, шпанском и 
језичких утицаја, 2) трансференцију, која означава појаву преношења елемената, обележја и правила из једног у неки други језик, са својим последицама са аспекта језичког система, у синхронији и дијахронији у посредном и непосредном контакту (настајање дијаспоралних језика, промене у стандардним језицима и сл.), а са аспекта комуникације билингвалног говорника 3) прекључивање кода и 4) замену језика. Ми их посматрамо централним предметом изучавања језика у контакту и језгром контактне лингвистике.

Када говоримо о контактолошким истраживањима и разграничавању појава, процеса и исхода и појмовних одређења, потребно је пре одређивања, дефинисања и именовања процеса и исхода језичког контакта пре свега разлучити следеће дихотомије: 1) врста контакта (посредни/непосредни контакт), 2) утицаји међујезичког контакта на говор/систем према врсти контакта, односно одражавању утицаја језика под контактом у равни синхроније и дијахроније, као и 3) утицаје језичког контакта у зависности од степена билингвалности, и на њима заснивати свако даље теоријско полазиште.

Ослањајући се на М. Клајна, Фелдеса (Фелдес 2005: 74-76) и Рил (Рил 2009: 28), из терминологије контактне лингвистике потпуно избацујемо појам интерференције, који остављамо у домену процеса усвајања језика и одлучујемо се за појам трансференције. Под трансференцијом подразумевамо процес, тј. појаву преношења речи, елемената, структура и структурних обележја и образаца из језика Б у језик А - заједничку како за посредни тако и непосредни контакт - што доводи до мешања језика на разним плановима језичког система. Према нашем мишљењу у основи посредног и непосредног контакта је један те исти феномен ${ }^{5}$ који као окидач за многе процесе у међујезичком контакту има различита исходишта. И у посредном и у непосредном контакту производ трансференције је трансфер. Међутим, трансфери у посредном и непосредном контакту попримају различити животни пут и доживљавају различите лингвистичке судбине. У посредном контакту трансфер у језику примаоцу постаје део језичког блага стандардног језика као посуђенища са

др. - и одражава историју колонијализма. Креолски језик је пиџин који је постао матерњи језик неке заједнице (уп. Кристал 1987: 334, 337).

${ }^{5}$ У том смислу делимично бисмо се сложили са мишљењем Јухаша (1970) који разликује интерлингвалну интерференцију која се јавља под општим условима вишејезичности и ону која се јавља приликом учења страног језика, где утицај тог страног језика на матерњи има скоро занемарљив утицај и обрнуто. Оно што је заједничко интерференцији и трансференцији јесте да своја полазишта имају управо у контрасту између језика А и језика Б. Како Јухаш каже, са психолошког становишта реч је о једној те истој појави, само је лингвистички исход другачији (Јухаш 1970: 32). Међутим, у светлу глобализације и утицаја енглеског језика као lingua franca може се делом и оповргнути његов став о „занемарљивом” утицају страног језика на матерњи у монолингвалној средини. У многим истраживањима се доказало да се под утицајем енглеског језика у српском језику јавља конвергенција као исход међујезичког утицаја и у посредном контакту, (видети ниже). 
различитим фазама и степеном адаптације на свим језичким плановима и статусом у језику примаоцу. ${ }^{6}$ У језику примаоцу у посредном контакту може услед учестале трансференције доћи и до конвергенщије, што је случај како у непосредном, тако и у посредном контакту (нпр. тренутни глобални утицај енглеског језика). Тако трансфер у виду посуђеница и конвергенције као резултати трансференције заједно утичу на промену стандарда дотичног језика и живи као такав на синхроној и на дијахроној равни. ${ }^{7}$

У непосредном контакту, а овде се ограничавамо на непосредни међујезички контакт у билингвалној средини без диглосије, дакле у миграциионм/ исељеничком контексту, посматрамо стање и понашање језика А у животном циклусу дотичне билингвалне заједнице. ${ }^{8}$ Производ трансференције у оваквом непосредном међујезичком контакту такође називамо трансфер. Међутим, овакав трансфер 9 даље утиче на структуралне промене језика А и можемо га пропратити у скоро свим системским равнима језика А као неасимиловани или адаптирани тансфер. Под деловањем силе таквих трансфера настаје језик који смо назвали српским језиком немачке дијаспоре. ${ }^{10}$ Он се као такав под утицајем трансференције и конвергенције све више удаљава од стандардног језика матице. Његова обележја су, по нашем мишљењу, непостојање синхроније и дијахроније у десосировском значењу. Овде је пре реч о постојању језичког динамизма у синхронији (Клајн 1975: 40), при чему се дијахронија дијаспоралног језика улива у тренутак када се и завршава животни циклус билингвалне заједнице. Може се чак рећи и да овај језик заправо и нема дијахронију, да је његов говор уједно и његов систем. ${ }^{11}$

${ }^{6}$ О фазама адаптације видети М. Клајна (1975), Филиповића (1986: 38), Беца (1974).

${ }^{7}$ Ова појава има више извора, медији, технолошки и културолошки утицаји, али уласком нових лексема или језичких конструкција кроз социокулутролошке контакте у језик матице монолингвалне заједнице. М. Клајн такође каже да трансференција обухвата појаве и код монолингвала (Клајн М. 1975: 16).

${ }^{8}$ Маки (1987) одређује и нешто што назива животни век двојезичне заједнице; за трајање једног таквог животног циклуса постоје разиличити наводи, а Маки полази од 10 до 100 година.

${ }^{9}$ Адаптирани или не, трансфери у говору, који могу бити и ad hoc или већ устаљени трансфери у умирућем систему језика А. Ове трансфере такође можемо анализирати по узору на посуђенице у посредном контакту у погледу адаптације.

${ }^{10}$ Термин дијаспорални језик који смо користили у необјављеној докторској дисертацији овде бисмо сменили термином језик дијаспоре, односно још презицније у контексту нашег истраживања језичког пара немачко-српски, српски језик немачке дијаспоре.

${ }^{11}$ Користећи се Вајнраховом (Вајнрајх 1976: 27) метафором да је интерференција налик песку који се таложи на дну реке, у миграционом контексту језичког контакта не постоји „таложење”, односно и ако постоји, онда је оно кратког века, тачније ова метафора са становишта језичког динамизма у миграционом контексу не би могла, рекли бисмо, овде да се примени, будући да билингвална заједница има ограничени век трајања. 
У погледу терминолошких разграничења појмова матерњи, први/други, примарни/секундарни језик, наследни или завичајни језик, страни језик, језик дијаспоре постоје бројне теоријске поставке и терминолошка решења, а које се тичу одређивања српског језика у дијаспори (уп.һирковић 2017: 521-524; Дурбаба 2011, Јовановић, www.dml.rs). ${ }^{12}$

Ми се овде опредељујемо за термин српски језик немачке дијаспоре пре свега потакнути констатацијом да је немачки језик исељеника у Бразилу, који је трпео језички утицај португалског као „потпуно страног” језика, било теже разумети него немачке дијалекте у Северној Америци, где је немачки био под утицајем једног сродног језика (Фелдес 2002: 9). Имајући у виду ову тврдњу, сматрамо да је оправдано питање до ког би се степена Срби из различитих региона европске дијаспоре међусобно могли споразумети и разумети. ${ }^{13}$ Такође смо мишљења да се термин наследни језик који се користи у новијим истраживањима, а и у образовно-политичким документима, најпре везује за језик потомака мигранта и њихову хронологију усвајања истог, будући да се наследни језик дефинише као језик који је по редоследу усвајања био први, али у већини случајева није у потпуности усвојен због преласка дотичног појединца на доминантни, већински језик (Јовановић, www.dml.rs ). Термин (српски) језик (немачке) дијаспоре има шире значење, те се не односи само на спрски језик и језичке компетенције потомака (радних) миграната, већ представља језик којим се дотична етнолингвистичка заједница служи у интергенерацијској и интрагенерацијској комуникацији у одређеним доменима и друштвеним мрежама.

Други резултат трансференције у испитиваном непосредном контакту јесте конвергенщија ${ }^{14}$, која је резултат интензивног и непосредног међујезичког контакта, те услед учестале трансференције долази до структуралног изједначавања „слабијег” језика А (овде српски) по узору на доминантни језик Б (овде немачки) (Фелдес 2002: 16; Клајн 2003: 79; Вестергард 2008: 274; Клајн 1975: 99). Као такав, реорганизован у својој структурној шеми, језик А се даље природним путем преноси са једног на други нараштај миграната. Будући да трансференција почива на контрастима између језика А и језика Б, јасно је да се под трансференцијом подразумева преношење „непоклапања”, тачније одступање од норме језика А, с тим што је за разлику од интерференције у усвајању језика, производ тог одступања стварање и настанак једног

${ }^{12}$ Термини који су се користили или се користе у досадашњим и новијим истраживањима као синонимне варијанте за овде употребљени појам (српски) језик (немачке) дијаспоре јесу: завичајни језик, породични, мигрантски и наследни језик (уп. Ћирковић 2017: 522)

${ }^{13}$ Ова чињеница повлачи за собом и питање осмишљавања адекватне наставе за ученике чији је наследни језик српски језик немачке, француске, америчке, шведске итд. дијаспоре.

${ }^{14} \mathrm{O}$ конвергенцији и контактнолингвистичким концептима посуђивања уп. Клајн 2003 и Филд 2002. 
„новог” језика, чије нам форме и структуре дају увид у начине међујезичких утицаја. ${ }^{15}$

Услед слабљења и губитка компетенције у језику А, а под утицајем разних социолингвистичких фактора, у језичкој пракси билингвалних особа долази као обележје фаза процеса замене језика и до прекључивања кода.

Трансференција и прекључивање кода ${ }^{16}$ спадају код многих билингвалних говорника у билингвалној заједници у њихове језичке репертоаре и представљају једну посве природну последицу дугогодишњег и интензивног језичког контакта (Пелка 2006: 55), те их не треба вредновати негативно. Они једноставно представљају фазе и стања једног језика унутар животног циклуса једне билингвалне заједнице у процесу замене језика А језиком Б, тј. потпуног умирања језика А и преласка на монолингвалну заједницу, што се може догодити већ и у другој генерацији миграната. ${ }^{17}$

Трансференција, конвергенција и прекључивање кода као појаве које прате животни циклус једне билингвалне заједнице не иду тако далеко да се завршавају заменом језика, како се пита Вајнрајх (Вајнрајх 1976: 92), и не воде непосредно у замену језика, већ језик А доводе у један одговарајући стадијум, тј. фазу животног циклуса. ${ }^{18}$ Доминантност језика Б и језика $\mathrm{A}$ варира из генерације у генерацију, те степен билингвалне компетенције услед испреплетаности социолингвистичких фактора подлеже померању. Све мањи степен билингвалне компетенције у корист језика средине (као и свесно одустајање од употребе језика А доводе до коначног преласка у другу монолингвалност.

${ }^{15}$ Према томе, трансференција наступа код билингвалног говорника у оним истим случајевима који се могу јавити као интерференција код ученика страног језика, али је исход утицаја језика под непосредним контактом другачији.

${ }^{16}$ Ови феномени, наравно, подлежу индивидуалним и специфичним разликовањима, а њихова појава варира у зависности од саговорника, теме, познавање језика и варијетета српског језика којим су се Срби друге и треће генерације служили као моделом приликом учења српског језика.

${ }^{17}$ Разлике у последицама и исходима језичког контакта у различитим етапама животног циклуса једне билингвалне заједнице ваља потражити у квантитативним и квалитативним условима контакта као и у временској димензији контаката. Тако смо, на пример, у истраживаном корпусу забележили више породица у којима је већ у другој генерацији уследио потпуни прелазак на другу монолингвалност, али и породицу у којој се и у петој генерацији очувао српски језик, и не само то, већ се и даље преноси.

${ }^{18}$ Трансференција као процес не доводи непосредно до замене језика, али се језик А, сада одевен у ново рухо, одржава у једном протоку животног циклуса као стање које садржи све мањи степен билингвалне компетенције. 


\section{3. АНАЛИЗА УПОТРЕБЕ СРПСКОГ ЈЕЗИКА}

Спроведено истраживање имало је за циљ да на основу анализе језичких и ванјезичких аспеката утицаја немачког језика на српски језик првенствено три генерације радних миграната у СР Немачкој у конкретној говорној заједници (Инголштат, Баварска) пружи, између осталог, одговоре на питања која се тичу фактора релевантних за процесе очувања или замене језика. Проучавање промена у српском језику и процеса замене српског немачким језиком у говорној заједници Срба у Инголштату захтевало је прикупљање грађе која се темељи на живом говору припадника истраживане заједнице, тачније снимљеним интервујима у трајању од 53,5 сати. Ти сати стали су на 400 страна транскрипта. Интервјуима је обухваћено 27 породица са 83 испитаника, а теренско истраживање обављено је у три етапе у периоду од јуна 2010. до октобра 2013. године. ${ }^{19}$

Однос доминантности употребе српског или немачког језика од генерације до генерације доводи до померања домена употребе као и до промена у структури српског језика, те је у вези са процесом замене језика уско везан и појам генерације. На овом месту дајемо кратко појашњење нашег поимања овог појма. Имајући у виду различите приступе одређењу појма генерација радних миграната, ми под првом генерацијом радних мигранта подразумевамо оне мигранте који су дошли у земљу пријема ради запослења шездесетих и седамдесетих година 20. века (уп. Филиповића 1986). ${ }^{20}$ Међутим, како су се у друштвеним мрежама испитиваног узорка радне миграције затекли и припадници миграционог таласа ратних деведесетих година 20. века са подручја бивше Југославије, у ову поделу на генерацијске типове уводимо и тип који

${ }^{19}$ Интервјуе са испитаницима обављали смо једним делом у породицама испитаника (20 породица), са једном испитаницом у њеној канцеларији у граду (будући да живи у предграђу Инголштата, било је компликовано организовати породичну посету), са трима испитаницима једне породице у кафићу, у Српском културном удружењу (5 представника прве генерације радних миграната) и у термину наставе српског језика (са 23 деце, представницима треће генерације радних миграната и друге генерације миграната четвртог таласа). У неким породицама непосредно посматрање спроведено је приликом прослава и дружења (породица А, Пш), активности Удружења, а и током пробе фолклора, на смотри српске заједнице у Инголштату поводом градске свечаности и сл., дакле у различитим комуникацијским ситуацијама. Неки испитаници били су чак присутни и у разговору са другим породицама и испитаницима. На пример, представник породице Ан био је присутан током разговора са породицом Ш, породицом J и у разговору са његовом генерацијском групом у просторијама Удружења, један представник прве генерације радних миграната породице П поред обављеног интервјуа у породичном окружењу био је присутан и приликом интервјуа у Удружењу са представницима прве генерације радних миграната.

${ }^{20}$ Истражујући непосредно посуђивање у језику досељеника у САД, Р. Филиповић (Филиповић 1986: 51) као прву генеращију одређује досељенике рођене у земљи језика примаоца који су у САД са собом понели локални говор или дијалект краја у коме су рођени, а припадницима друге генерације сматра оне који су рођени у земљи језика даваоца. 
називамо првом генерацијом четвртог таласа миграција, а њихов нараштај, рођен у земљи пријема, другом и трећом генераџијом четвртог таласа миграција. ${ }^{21}$

У припаднике друге генеращије убрајамо децу прве генерације и делимо их на три категорије:

- на децу која су доведена у Немачку, тј. другу генерацију muna 1a) и 1б),

- децу која су у Немачкој рођена, тј. другу генерацију типа $2^{22}$ и

- ремигранте друге генерачије радних миграната.

Поредећи Плачкову поделу (Плачко, 1977: 27) са нашом, друга генерација по Плачку је у нашој подели друга генерација првог типа, а његова трећа генерација за нас је друга генерација другог типа.

Међутим, анализа истраживаног корпуса наметнула је још један тип припадника друге генерације, који чине испитаници који су у неком животном добу доведени у Немачку или су се у Немачкој родили, затим су у одређеном узрасту враћени у Србију, да би се опет у извесној животној доби поново вратили у Немачку. Тај тип припадника друге генерације називамо ремигрантима друге генерације радних миграната.

Велики број припадника друге генерације је по завршетку школовања наставио да живи у западноевропским земљама, укључујући се на тржиште рада тих земаља и склапајући тамо своје бракове (Давидовић 1999: 22). Деца друге генерације миграната представљају трећу генеращију говорника радних миграната у дијаспори.

Оно што се из истраживаних ситуација могло закључити о интрагенерацијској и интергенерацијској комуникацији и пратећим феноменима језичког контакта сажето приказујемо у наредним редовима рада, са одговарајућим илустрацијама говора испитаника.

${ }^{21}$ У међувремену је од тренутка истраживања до данас дошло до значајних миграционих померања, чији се почетак наговештава у поменутој необјављеној дисертацији уз позивање на податке Министраства здравља Србије. Може се рећи да се данас у склопу савремених миграција Срба 21. века, пре свега у немачкој дијаспори, већ налази прва генерација петог таласа миграција. О таласима миграција видети даље код Павлица (Павлица 2005) и Ивановић (Ивановић 2012).

22 У нашој подели на ове две важне подгрупе друге генерације првог типа, које су доведене у Немачку, прекидајући им тако ток језичког развоја (функције воље, емоције и интелекта које се развијају хронолошки и хијерархијски) наслањамо се на Љ. Рајића, који је истраживао језик деце миграната у Шведској (Давидовић 1999: 84, 87, 88). У другу генеращију типа 1a) сврставамо децу која су у земљу пријема доведена у току или након окончања примарне и почетка секундардне социјализације (до 12. године живота), у другу генерацију типа 1б) сврставамо децу која су у земљу пријема доведена у току или након завршетка секундарне социјализације (између 12. и 18. године живота). 
Припадници прве генераичје радних миграната у интрагенерацијској комуникацији користе искључиво српски језик који се одликује првенствено лексичким асимилованим и адаптираним трансферима, повременим прекључивањем кода, углавном приликом цитирања туђих речи, и ретком појавом граматичке трансференције.

На пример:

(1) [...] ово све што стоји ту, то сам ја правио |...| (прекид исказа, обраћа се испитаници, која је нешто подигла) <*nee, nee lass das $>$, остави, остави $|/|$ са мојим рукама и [...] то је (--) $<$ хмм $><*$ херштелер $>$ прои звођач[...];

/испитаник прве генерације радних миграната породице П у разговору са супругом ${ }^{23}$ код куће/;

или

(2) $[\ldots]$ и без спавања може да се установи [...] имају различите методе са (-) са оним апаратима и са $<* *$ геретима $>[\ldots]$ она може да извр $(-)|/|<* *$ ay $|$,$| ау |$,$| аусвертује >[\ldots]$ ако има $<* *$ аусзеце $>$ или ако има сметње $[\ldots]$;

/исти испитаник, овде у разговору са припадницима своје генерације, у Удружењу/

Исти начин комуникације и исте пратеће појаве језичког контакта карактеришу интергенерацијску комуникацију прве, друге генерације радних миграната, ремиграната друге генерације, прве генерације четвртог таласа и четврте генерације миграната првог таласа. У говору неких припадника генерацијских групација које не припадају првој генерацији радних миграната долази до интензивније употребе како асимилованих/адаптираних тако и неасимилованих лексичких трансфера, као и већег степена граматичке трансференције.

На пример:

(1) $[\ldots]$ мени фали она (--) <** мате> [...] еј, ево га онај $<*$ Tortenboden $>$ $[\ldots .] ;.[.$.$] Чика П., понесите горе <*$ Seife und Spülmittel $>$ [...]; /испитаница Јм, друга генерација типа 1а, у разговору са испитаником Ан, прва генерација радних миграната/.

Интрагенерацијска комуникација друге генерације радних миграната,четврте генерације мигранта првог таласа и ендогама карактерише употреба српског језика као главног, а немачког као споредног језика.

${ }^{23}$ У породици овог испитаника је наступила друга монолингвалност већ у другој генерацији радних миграната типа 1a; у кући се увек говорио и говори немачки, поред тога супруга је Немица из Вовјодине. 
Оваква комуникација праћена је лексичким и граматичким трансференцијама и већим степеном прекључивања кода.

На пример:

(1) $[. .$.$] ја сам купила <*$ zwei Tischdecken $>$ и на $<*$ achtziger Durchmesser $>$ сам <*ausprobiert>, али не $<* *$ паше $>$ [...];

/испитаница Јм, друга генерација типа 1а, у разговору са представницима друге генерације радних мигранта/;

(2) $[\ldots]$ имамо $<*$ Kerzen $>$ y $<*$ Angebot $>[\ldots] ;[\ldots]$ они мени сви, јаaаoj, $<*$ sind Sie verspannt $>$ и ја кажем, не мора она мени да прича, ја знам све то, наравно, то је све <*akute Anspannung über den ganzenTag>, него ето ја сам $[. .$.$] ;$

/представница ендогама Пшс у разговору са другом генерацијом миграната, другом генерацијом ремиграната и ендогамима/;

(3) [...] радовала се два дана (--) стварно се радовала, иначе, каже $<*$ morgen, ganz Sport, jaаa $>$ она $<*$ liebt Sport $>$ баш радује се $[. .$.$] ; ис-$ питаник Пшг, друга генерација миграната другог типа, у разговору са другом генерацијом миграната, ендогамима и ремигрантима друге генерације/.

У трећом генерацијом радних миграната, другом генерацијом миграната четвртог таласа и петом генерацијом миграната првог таласа употреба српског и немачког варира од породице до породице. У неким породицама се родитељи доследно придржавају подељених језичких улога ${ }^{24}$ (нпр. породица Ла), у неким породицама се родитељи обраћају деци на српском, а деца одговарају на немачком (нпр. породица Пш, Ђ). Нека деца строго раздвајају језике, па када им се неко обрати на српском, одговарају на српском и обрнуто (нпр. породица Пр, Ст). Такође смо приметили да и међу родитељима у комуникацији са трећом генерацијом има оних који прекључују језике:

${ }^{24}$ Овај начин стицања билигнвалности познат је као ОПОЛ-метода (енгл.: OPOL, cкраћеница од: “One Person - One Language”). Овај појам 1902. године први употребљава француски лингвиста Морис Грамон (Maurice Grammont) (уп. Barron-Hauwaert, Suzanne (2004), Language Strategies for Bilingual Families, https://books.google.rs, приступљено 08.01.2020); он развија теорију да родитељи у комуникацији са децом строго раздвајају језике, те је сваки родитељ задужен за комуникацију са дететом искључиво на једном од језика. Овај се приступ и данас примењује и у билингвалним обдаништима (уп. kita.de: Bilingualer Kindergarten: Alles zur zweisprachige Kinderbetreuung.). О примени ове методе посебно је писала и истраживала С. Липерт (2010, 2013), док је С. Ромејн (1989) направила класификацију шест модела остваривања билингвалности, где је ОПОЛ-метода један од наведених. 
(4) Пшб: <*M., M, komm mal her> ако имаш време мало да причаш с њим, па неки питања да те пита и ти да одговараш [...] Пшми: ОК. Пшб: $<*$ Mit Interview (-) Aufnahme mit dem Ding (-) kommt alles auch im serbischen Fernsehen> [...]; Пшми: <*Was?>; Пшб:<*Ich mach Spaß>, шалим се. Пшми: Ја ћу то да пробам.

/разговор испитанице Пшб, друга генерација радних миграната типа 2 са испитаницом Пшми, трећа генерација радних миграната, пасивни билингвал/;

или:

(5) [...] понекад чујемо, овај, је л’ да, Б., понекад чујемо (--) <*dass Serbisch gesprochen wird $>$ овде у $<*$ M.>[...];

/разговор испитанице Ђб, друга генерација радних миграната типа 2, са испитаницомЂбо, трећа генерација радних миграната, пасивни билингвал/.

Такође смо у оваквој интергенерацијској комуникацији приметили да се у свакодневном животу пре користи немачки језик, како би се неки посао или задатак брже обавио. Као разлог томе испитаници наводе слабије компетенције треће генерације радних миграната на српском језику, тачније теже разумевање и спорије продукције на српском. ${ }^{25}$

Tpeћа генерација радних миграната у својој интрагенерацијској комуникацији користи искључиво немачки језик. Дакле, трећој генерацији немачки језик је на основу компетенције и функиије језик интрагенерацијске комуникације, док одређивање матерњег језика према критеријуму идентификаиије може варирати од случаја до случаја.

Тако више од половине испитаника, наиме $60 \%$, сматра да је њихов матерњи језик српски. У тај проценат спадају првенствено припадници прве генерације радних миграната, ендогами, представници прве генерације четвртог таласа и ремигранти друге генерације радних миграната. Оно што је интересантно у овом резултату јесте да има и оних испитаника који кажу да им је српскохрватски матерњи језик (међу припадницима прве и друге генерације радних миграната). Такође, један испитаник је на питање који му је матерњи језик дао одговор, који овде верно преносимо: „југо-дојч”. Најразуђенију слику по питању матерњег језика даје трећа генерација радних миграната. Од 31 испитаника ове генерације четрнаесторо изјављује да има два матерња језика, али од њих 9 испитаника даје предност српском, а 5 немачком језику. Девет испитаника изјавило је да им је матерњи језик немачки, а 8 испитаника рекло је да им је матерњи језик српски. Опредељење потоњих испитаника за

${ }^{25}$ Рецимо, испитаница породице А, припадница друге генерације ремиграната, нам је у једној таквој комуникацијској ситуацији рекла: „Овако то код нас иде, брже је на немачком, да сам јој рекла на српском, питала би 'Шта, како?' и то би потрајало.” 
српски као матерњи језик се не поклапа са њиховом компетенцијом на српском језику, те овај податак говори о очувању идентитета припадника треће генерације миграната и степену њихове интеграције и асимилације у друштво већинске заједнице. Њихов став је углавном одраз става саме породице према вредностима као што су језик, култура и идентитет. Али, то не мора увек бити случај. У нашем истраживаном корпусу у породицама Пш (испитаница Пшб, друга генерација радних миграната другог типа) и Ан (представници друге генерације типа 16 и типа 2) и представници треће генерације поред негативног става родитеља према очувању српског језика желе да науче српски језик. Међутим, главни проблем јесте овде недостатак одговарајућих друштвених мрежа у којима би се развијале њихове компетенције на српском језику. Тако је испитаница Пшми пасивни билингвал, док су у породици Ан представници треће генерације миграната монолингвали на немачком језику.

Приликом породичних интервјуа дешавало се, међутим, да деца међусобно разговарају и на српском и на немачком, са прекључивањем кода, на пример:

(6) [...] Д., <aax> је л` си знала како полиција има онакав (-) $<*$ Schild $>$ a онда $<*$ sagt uns, das haben sie kaputt gemacht $>[\ldots]$;

/разговор два припадника друге генерације миграната четвртог таласа, породица Кр/.

У неким породицама родитељи инсистирају да деца међусобно користе српски језик, али без успеха:

(7) [...] деца међусобно [говоре] више немачки, некад и викнем, кажем, рекли смо српски и онда пребаце, али опет брзо се врате на немачки $[\ldots]$;

/испитаница Ар, ремигрант друге генерације/.

Неки испитаници су у разговору са истраживачем водили рачуна о томе да користе што коректнији српски језик са што мање трансферисаних лексема. Међутим, и даље у присуству истраживача, али у обраћању припадницима своје породице, њихов српски језик одликовао се лексичким трансферима у виду асимилованих/адаптираних и неасимилованих лексема и/или прекључивања кода.

(8) Слушај ме сад добро С., све што J. <**ауфнема > (-) то неће (--) <*nicht, nie $>$ доћи (--) $<*$ in die Öffentlichkeit $>[\ldots]$;

/испитаник Жа, друга генерација другог типа, у разговору са сестром Жс, припадницом друге генерације ремиграната /;

(9) Пот: А <** гешихте>? Пус: А, да историја (-) радимо (-) сад |... Пот: Који период који је то $<* *$ цајт $>$ ? Пус: $<*$ Neuzeit $>$. Пот: Који, $<*$ нојн- 
центерјархундерт, званцигстерјархундерт>, коју историју учите, који $<* *$ гешихте $>$ ?

/разговор испитаника Пот, прва генерација миграната четвртог таласа, са сином, испитаником Пос, трећа генерација радних миграната/;

(10) Хало, е, је л` мама ту (-) оћеш да ми даш <ем> пита она (--) J. |... ок иии $<$ ем $>$ ми ће да једемо сад пицу $<*$ und ich ruf dich dann wieder an ok, ja, also, so, ja, ja ich weiß, gut $>$ ajде $<*$ jaaa (---) aber du kommst $>$ добро, добро, ајде, немам више $<*$ Guthaben $>$ ћао.

/разговор испитанице Цј, трећа генерација радних мигранта са мајком, испитаницом Цн, ремигрантом друге генерације/;

(11) Јн:<*Komm mal her, komm her! > Jc: Шта је било? Јн: $<*$ Komm her! >Jc: Јел`сте се посвађали? Јн:<* Ja, komm her!>Jн: $<*$ Ich nehme ein Stück.>Jc:Али, полако, немој, распада се, е, узми Миланов. Јн: Не распада се. Jc: $<*$ Doch, doch>, узми Миланов!

/разговор између испитанице Јс, друга генерација радних мигранта другог типа и сина, испитаника Јн, трећа генерација радних миграната/.

У комуникацији са истраживачем су поједини испитаници улагали доста напора да задрже континуитет разговора на српском.У њиховом говору долазило је до блокирања лексичких и граматичких трансференција, неутрализације, тачније узастопног понављања речи или исказа и на српском и на немачком језику, до блокирања прекључивања кода или прекључивања кода са неутрализацијом:

(12) $[\ldots]$ а писмо, је л си знао $<* \operatorname{Re}>|/|$ слова [...]; [...] у 4 сата имате ту сат и по $<*$ Un $>/||$ наставу [...];

/испитаницаРм, друга генерација типа 16 , хтела је да каже 'Rechtschreibung', а испитаник Рд, друга генерација типа 1б, породица P, је хтео да каже 'Unterricht'/

(13) $[\ldots]<*$ jedefalls $>$ у сваком случајy $<*$ kein $>$ кревет $[\ldots]<$ иии $>(---)$ у то време $(-)<*$ das $\mathrm{w}>|/|$ то је било $<*$ ja $>[\ldots]$;

/испитаник К, прва генерација радних мигранта, испитаник је хтео да каже 'das war' $\%$

Говор свих испитаника је био праћен конверзационим карактеристикама које генерално указују на начин опхођења билингвалне особе са својим дефицитима у компетенцији, попут поштапалица, уздаха, промене исказа, понављања слогова или речи, колебања у говору и сл. 


\section{4. ЗАКЉУЧАК}

У периоду трајања животног циклуса једне билингвалне заједнице стање мањинског језика и понашање припадника говорне заједнице мањинског језика се мењају. Ове промене су условљене утицајем друштвених и језичких фактора, а које се даље одражавају и на приказану интергенерацијску и интрагенерацијску комуникацију испитаника. То су према нашим резултатима пре свега социолингвистички фактори који се тичу начина усвајања српског језика и односа и контаката са матичном земљом. Док су испитаници друге генерације миграната типа 1а и 2 српски језик у миграцији усвајали као први језик у породичном домену и поред тога били све до постојања СФРЈ у обавези да похађају југословенску допунску школу, дотле трећа генерација радних миграната одраста у потпуно другачијим друштвеним околностима. Деведесетих година 20. века економске и политичке промене у некадашњој матичној држави Југославији за резултат имају укидање југословенских школа и гашење југословенских клубова. Услед ових друштвених кретања друга генерација радних миграната одлучује се за трајни боравак у Немачкој. Тиме се код многих јавља питање да ли српски језик уопште да преносе својој деци. Ова промена друштвених околности и личног става друге генерације радних миграната одражава се како на хронологију усвајања језика, тако и на степен билингвалности припадника треће генерације радних миграната. Друга генерација радних миграната је сем тога, за разлику од треће, имала густе сегрегиране друштвене мреже у приватном и пословном домену - становање, слободно време (југословенски клубови), југословенска школа - и интензивније контакте са матицом. Код треће генерације ови домени и друштвене мреже или више не постоје или су јако ослабљени. Ови фактори свој одраз налазе у приказаној употреби српског и немачког језика унутар и између генерација.

Тако су испитаници прве генерације радних миграната у интрагенерацијској комуникацији, као и у комуникацији са истраживачем користили искључиво српски језик. Исти начин комуникације карактерише интергенерацијску комуникацију прве, друге генерације радних миграната, ремиграната друге генерације, прве генерације четвртог таласа и четврте генерације миграната првог таласа и ендогама. Интрагенерацијску комуникацију друге генерације радних миграната одликује употреба српског језика као главног, а немачког као споредног језика. У интергенерацијској комуникацији свих горе наведених генерација са трећом генерацијом радних миграната, другом генерацијом миграната четвртог таласа и петом генерацијом миграната првог таласа употреба српског и немачког варира од породице до породице. Трећа генерација радних миграната, друга генерација миграната четвртог таласа и пета генерација миграната првог таласа у својој интрагенерацијској комуникацији користе искључиво немачки језик. Приликом породичних интервјуа, 
на пробама фолклора и часовима српског језика може се, међутим, приметити да деца међусобно разговарају и на српском и на немачком језику са честим прекључивањем кода.

Посматрањем комуникације испитаника са истраживачем и у међусобној комуникацији испитаника током интервјуа дошло се до занимљивих констатација. Неки испитаници су у разговору са истраживачем водили рачуна о томе да користе што коректнији српски језик са што мање трансферисаних лексема, али су у комуникацији са припадником своје породице користили српски језик са адаптираним/неасимилованим лексемама и/или прекључивањем кода. У комуникацији са истраживачем су поједини испитаници улагали доста напора да задрже континуитет разговора на српском, па је је њихов говор био пропраћен конверзационим карактеристикама попут уздаха, пауза, колебања у говору. Такође, често је долазило до блокирања лексичких/граматичких трансференција и прекључивања кода, негде са појавом неутрализације, тачније узастопног понављања речи или исказа и на српском и на немачком језику. Без обзира на разлике квалитативног и квантитативног типа, у анализи лексичких трансференција су идентификовани лексички трансфери који су заједнички свим испитиваним генерацијама и групацијама. То доводи до закључка да су они већ постали делом лексикона српског дијаспоралног језика испитаника.

Степен присутности одређених трансференција сведочи о томе да се језик прве генерације радних мигранта, ендогама, прве генерације миграната четвртог таласа немачком језику највише приближио на лексичком плану, док је језик друге, а првенствено треће генерације, умногоме попримио структурална обележја немачког језика. Конфигурација доминантности језика је потпуно промењена и говорници прве и друге генерације српски језик свесно престају да користе управо због треће генерације која је или пасивно или рецептивно билингвална.

Даља анализа је показала да је у испитаном узорку српски језик као главни језик општења заступљен у 9 породица, у 5 породица српски полако губи примат, у 2 породице су и српски и немачки подједнако заступљени, док је у 13 породица немачки главни језик комуникације у породици ${ }^{26}$. Од укупног броја у 7 породица је већ дошло до замене језика. Према процени на основу сазнања о ставовима, језичком понашању и употреби, српски језик има будућност да опстане као споредни језик општења у 17 испитаних породица. Код ових 17 породица се и друштвене мреже приватног домена састоје од јаких, слабих и пасивних веза у матици и миграцији, прате се медији на српском језику, а

${ }^{26}$ Овде је укупан збир породица 29, будући да смо овде као засебне рачунали породицу ремигранта Жс друге генерације породице Ж и породицу представнице друге генерације радних миграната другог типа Пшб породице Пш. 
десет је породица у моменту истраживања активно учествовало у раду српског културног удружења „Свети Сава”. Према нашем мишљењу, судбина српског језика посматране три генерације радних миграната је у рукама треће генерације. Да ли ће и на који начин ова генерација бити у стању да српски језик даље преноси зависиће од сплета личних и друштвених околности: са једне стране најпре од типа бракова које буду склапали представници ове генерације, а са друге од заинтересованости државе Србије да створи друштвене мреже које ће поспешивати очување српског језика, идентитета и културе.

Данас, након готово седам година од спроведеног истраживања, у знању нам је да су се околности које су постојале у тренутку истраживања промениле у корист убрзане замене српског језика немачким језиком. Стога сматрамо да би било занимљиво и корисно за научну заједницу када би се образовањем тимова истраживача спровела нова теренска истраживања српског језика немачке дијаспоре у склопу неког дугорочног истраживачког пројекта на интердисциплинарним основама. То би свакако допринело како теорији контактне лингвистике и језичког контакта, тако и емпирији и практичном коришћењу резултата истраживања (очување језика, наставна методологија и сл.).

\section{ЛИТЕРАТУРА}

Бец 1974: W. Betz: Lehnwörter und Lehnprägungen im Vor- und Frühdeutschen, de Gruyter.

Барон Ховер, 2004: S. Barron-Hauwaert, Language Strategies for Bilingual Families, https://books.google.rs >, приступљено 08.01.2020.

Вајнрајх 1976: U. Weinreich, Sprachen in Kontakt: Ergebnisse undProbleme derZweisprachigkeitsforschung- 1. Aufl. München: Beck.

Вестергард 2008: A. Westergaard, Strukturelle und pragmatische Verwendungsmuster im bilingualen Sprachgebrauch bei Jugendlichen, Verlag Dr. Kovač: Hamburg.

Дурбаба 2011: О. Дурбаба, Билингвизам - предуслови, класификација и појавни облици, XVI, 589-600.

Зел 1988: H. Seel, Lexikologische Studien zum Pennsylvaniadeutschen: Wortbildung des Pennsylvaniadeutschen; Sprachkontakterscheinungen im Wortschatz des Pennsylvaniadeutschen, Franz Steiner Verlag Wiesbaden $\mathrm{GmbH}$ : Stuttgart.

Ивановић 2012: V. Ivanović, Geburtstag pišeš normalno Jugoslovenski gastarbajteri u Austrijii SRN 1965-1973, Beograd: Institut za savremenu istoriju. 
Jyxaш 1970: Juhász János, Probleme der Interferenz, München: Hueber.

Кристал 1987: D. Kristal, Kembrička enciklopedija jezika, Beograd: Nolit.

Клајн 1975: C. Michael, Forschungsbericht Sprachkontakt.Untersuchungsergebnisse und praktische Probleme, Kronberg/Taunus: Script Verlag.

Клајн 2003: C. Michael, Dynamics of language contact: English and immigrant languages. Cambridge, New York: Cambridge University Press.

Липерт 2010: S. Lippert, Sprachumstellung in bilingualen Familien zur Dynamik sprachlicher Assimilation bei italienisch-deutschen Familien in Italien, Waxmann, Waxmann Münster/New York/München/Berlin.

Липерт 2013: S. Lippert, Erhalt oder Verlust der schwachen Sprache in bilingualen Familien? Zeitschrift für Interkulturellen Fremdsprachenunterricht 18: 1, 132-145. Abrufbar unter http://zif.spz.tu-darmstadt.de/jg-181/beitrag/Lippert.pdf- приступљено 05.01.2020.

Павлица 2005: B. Pavlica, Migracije iz jugoslavije u Nemačku - migranti, emigranti, izbeglice, azilanti, www.doiserbia.nb.rs/ft.aspx?id=0025..., 21.10.2011. Bruxelles, NewYork, Oxford, Wien, BerlinerSlavistisch eArbeiten. Bd. 30, приступљено 05.01.2020.

Пелка 2006: D. Pelka, Der deutsch-polnische Sprachkontakt in Oberschlesien am Beispiel der Gegend von Oberglogau, Berlin: Trafo.

Рил 2004: С. M. Riehl, Sprachkontaktforschung: eine Einführung, Tübingen: G. Narr.

Ромејн 1989: S. Romaine, Bilingualism, Oxford: Blackwell.

Ћирковић 2017: Настава на српском језику у Поморишју данас, https:/izdanja. filfak.ni.ac.rs > casopisi > download, приступљено 09.01.2020.

Фелдес 2005: C. Földes, Kontaktdeutsch. Zur Theorie eines Varietätentyps untertranskulturellen Bedingungen von Mehrsprachigkeit, Tübingen: Verlag Gunter Narr.

Фелдес 2002: C. Földes, Kontaktsprache Deutsch: Das Deutsche im Sprachen- und Kulturenkontakt, edocs.ub.uni-frankfurt.de > Hochschulpublikationen, прегледано 24.09.2019.

Филд 2002: Fredric W. Field, Linguistic Borrowing in Bilingual Contexts. Amsterdam. 


\section{Електронски извори}

www.dml.rs > 333-ana-jovanovic-ucenje-nastava-srpskog-kao-naslednog-lat kita.de: Bilingualer Kindergarten: Alles zur zweisprachige Kinderbetreuung., приступљено 05.01.2020.

\section{GEBRAUCH DER SERBISCHEN SPRACHE IN DER INTER- UND INTRAGENERATIVEN KOMUNIKATION DER SERBEN IN DER DEUTSCHEN DIASPORA}

\section{Zusammenfassung}

Dieser Beitrag stellt einen Ausschnitt der Ergebnisse dar, zu welchen wir während der Erforschung des Sprachwechselprozesses der serbischen Sprache unter dem Einfluss des Deutschen im direkten Kontakt gekommen waren. Genauer gesagt handelt es sich hier um die gewonnenen Ergebnisse der Untersuchung, die zwischen 2010 und 2013 in der deutschen Stadt Ingolstadt in Bayern unter 27 serbischen Familien mit insgesamt 83 Probanden durchgeführt wurde. Im Beitrag wird ferner die Entstehung der Phänomene des direkten sprachlichen Kontakts sowie die Aufgabe der serbischen Sprache zugunsten der deutschen Sprache erörtert. In der Analyse, die auf empirisch gesammelten linguistischen und soziolinguistischen Daten basiert, untersuchten wir, wie sich der Zustand des serbischen Sprachsystems unter dem Einfluss des deutschen Sprachsystems aufgrund der lexikalischen, syntaktischen und morphologischen Transferenzen in einem sich von einer in die andere Einsprachigkeit bewegenden Prozess ändert. Dieser Beitrag befasst sich speziell damit, wie, mit welchen Mitteln und mit welchen begleitenden Phänomenen des direkten sprachlichen Kontakts Serben in der deutschen Diaspora die serbische Sprache in der interund intragenerativen Kommunikation verwenden.

Schlüsselwörter: intergenerative, intragenerative Kommunikation, Transfer und Transferenz, Code-Switching, Neutralisierung 